\title{
Ssciendo
}

Ethics \& Bioethics (in Central Europe), 2019, 9 (3-4), 119-130

DOI:10.2478/ebce-2019-0015

\section{Morals and culture at the time of Decameron}

\author{
Rastislav Maxinčák ${ }^{1}$
}

\begin{abstract}
The article is devoted to the theme of the moral condition during the Black Death epidemic in Florence within Boccaccio's group of young people in his Decameron. The disease in the region of Florence caused many existential and moral tragedies. A group of young people transferred the joy of life and moral principles to the gardens outside the city of the disease. They describe different moral and philosophical thoughts in their songs at the end of each day. ${ }^{2}$ These songs represent ten parts of nature and form the basis on which the allegorical character of the works is further developed. They are also carriers of the laws of nature and natural wisdom.
\end{abstract}

Keywords: Decameron cornice, Aristotle's ten categories, Black Death, epidemic, moral

\section{Introduction}

The world around us is not a vague whole. It works according to the principles which determine different ways of its functionalities. These principles form The Categories defined by Aristotle in his work of the same name. Aristotle describes the functioning of nature using these ten principles and The Physics ${ }^{3}$ interprets them. This is my own personal attempt to interpret Boccaccio's Decameron as an intellectual product of the times it was written in using references I have researched for the last five years.

"Since we are exploring nature as a beginning of movement and change, we must not neglect to define what movement is, lest unclearness about movement lead us into inevitable unclearness about nature; and then, having defined movement, we must in the same manner take up the terms which follow from it. Thus, movement being continuous, what is infinite becomes evident primarily in what is continuous, with the consequence that the continuous is often defined in terms of the infinite: "That is continuous which is infinitely divisible". In addition, movement is held to be impossible without place, the void, and time. Clearly, then, we must investigate and find out what we can about each of these topics, not only for the reasons stated but also because the features mentioned are general and common to all the things with which our science deals and a theory of special traits must come after theory of common traits" (Aristotle, 1961, p. 41). The Categories can be divided into ten parts as Aristotle presents them: substantia, quantitas, qualitas, ubi, quando, habitus, actio, situs, relatio, passio.

\section{Boccaccio and his Aristotelian cornice of Decameron}

The ten young people in Boccaccio's Decameron represent ten parts of nature and form the basis on which to develop allegory in the work. They are the carriers of the laws of nature and natural wisdom. Love is also the common character, which covers all the songs. From essence to passion, love in all its forms can cover a diverse identity of these ten young people in the harmony of life and its moral and sensible human existence laws. "Everyone says, I am, and then when he talks about his love, at the same time he also betrays his identity. Boccaccio in these verses brings together the original lyrics through a complex metamorphosis that reworks the doctrine by translating it into a language commonly used in love poetry. Only the person who knows the original text can identify it, cut out the verses of poetry, and make it again a

\footnotetext{
${ }^{1}$ Constantine the Philosopher University in Nitra, Faculty of Arts, Nitra (Slovakia); rossimaxi@hotmail.com

${ }^{2}$ A hundred novels are narrated in ten days, at the end of each day a song is sung by one of the characters of the cornice.

${ }^{3}$ The Physics takes its title from the Greek word phusis, which translates more accurately as "the order of nature"
} 
philosophical text. The way the author creates its own system of doctrine, shows his extraordinary abilities" (Gagliardi, 1999, p. 181).

Decameron is the story of the journey behind the search for natural wisdom, which determines the goodness and the greatness that a person can achieve in different situations of a separate and common existence. This path forms a framework in which individual novels are inserted in logical order. The young people, after leaving Florence, are switching from the negativity of the Black Death ${ }^{4}$ to the utopia ${ }^{5}$ of a new beginning. Their route is displayed on a map of symbolic events, which are, for them, to become stops on the road to knowledge. Their path forms their spiritual development, on which they must go through tragic events so that they can recreate the world, destroyed by the apocalypse of the Black Death and human inability to face destruction. The path forms a closed circle and the young people, after the search has successfully been completed, will eventually return to where it all started. They eventually find out that the meaning of being is living, which is also the meaning of the existence of man.

"The unclear silence of the joyful entertainment of young people hides the idea that is not to be clearly accessible, the deepest idea of Decameron. Poetry takes over the role of guardian of hidden ideas, disturbing ideas, intellectual expressions of faith in contrast with the power of prohibitions. What is illegal must become unreadable. In these songs one can understand how the author transforms syllogism ${ }^{6}$ into metaphors, and the forbidden language of poetry creates a mask under which the philosophical discussion can be further developed. The apron of irrelevancy, which poetry gives to the deepest idea, allows a silent dialogue with those living in the same intellectual harmony in the common understanding" (Gagliardi, 1999, p. 199). At the end of the day, ten songs reveal the intellectual identity of their performers, doctrinal content, and offer interconnectivity between love and sense through the ten Aristotelian categories.

The primary meaning of the work is the part of being, nature and everything. When you move to a lower level of text, you can discover that the work itself is organized in multiple layers. Through the symbols for the ten categories one penetrates the depth of the doctrine and the story itself, and discovers not only the core, which Boccaccio has inserted deep inside, but also a dialogue with his own times which highlights similarities and differences. Being is also an analogy that applies equally to all the categories. Being is good, true, substance, nature, life. Here, naturally, it is not for Boccaccio to define being as an existence, as a metaphysical abstract concept, but to verify its content in the context of the gender and human nature of the law. First, Boccaccio wants to verify the meaning of the claim: "The substance is the cause of the existence of all things, and for living things to exist is to live, and the soul is their cause and principle" (Aristotle, 2018, p. 28). Gagliardi writes in regard: "Boccaccio almost certainly is not the author of this symbolic statement. For symbols to be understood, they must be part of the Universe that communicates them. It is very likely that this statement originates in the intellectual environment of Florence, if it has not been part of the heritage of poets and painters" (Gagliardi, 1999, p. 202).

The path of the symbols is the same, on which the ideas come. The analogy of the fresco The triumph of death at the necropolis in Pisa was pointed to a few times. ${ }^{7}$ The theme of the ten Aristotelian categories, which can be seen in the ten young people (three men and seven

\footnotetext{
${ }^{4}$ The epidemic which devastated Medieval Europe, known as the Black Death, struck particularly hard among urban populations, including the Italian city of Florence. A major center of art, religion, and politics. Caused by the bacteria Yersinia pestis, it killed an estimated 30 to $60 \%$ of Europe's population.

${ }^{5}$ An imagined place or state of things in which everything is perfect.

${ }^{6} \mathrm{An}$ instance of a form of reasoning in which a conclusion is drawn from two given or assumed propositions (premises); a common or middle term is present in the two premises but not in the conclusion, which may be invalid (e.g. all dogs are animals; all animals have four legs; therefore all dogs have four legs).

${ }^{7}$ Triumph of death (former fresco, 14th century) attributed to Buonamico Buffalmacco at Camposanto of Pisa, Tuscany, Italy.
} 
women), has also been present in the intellectual circles around Boccaccio even before he published his works. Their voices reverse the symbolism of the fresco and transform the triumph of death into the triumph of life. "Fresco becomes an inverted text and the antidotes submit a dilemma that can only be resolved by the one who knows its logic and rules" (Gagliardi, 1999, p. 202).

Songs are built to duplicate the meaning and truth, on a double level of clarity and assume two different readers. One who knows the rules can decipher the hidden meaning. A reader who does not belong to an inner circle can only benefit from the surface of the text. Technical, logical and poetic knowledge links the text and allows its true meaning to pass under the obvious: its victim or culprit are not only victim of Brother Cipolla ${ }^{8}$ but they could also be other readers.

\section{Describing each character from Decameron and her/his songs at the end of each narrative day}

1) Emilia: Substantia, Substance ${ }^{9}$

The most important of the ten categories is substance. The term "substance" (ousia) is an abstract noun formed from the participle "being" (ousa). It might literally be translated as "beingness" (Cf. Phaedo 65e, where Plato says that the Forms are the ousia of sensible objects). ${ }^{10}$ The term is thus a traditional one, but Aristotle gives it the new prominence. "Looking at what he says about substance will reveal the main features of his "ontology", his understanding of what exists and of the nature of being. Aristotle takes the hallmark of substance to be that, if it did not exist, nothing else would either" (Bradshaw, 1998, p. 48).

The essence, which is present in the first story, is the first, Divine essence, God. According to the Aristotelian text, God talks about himself, about his naturalness. At the outset, only the indication of God can be noticed, while the second part of the text contains scattered components of the original text:

Whene'er I mirror me, I see therein. That good which still contenteth heart and spright. Nor fortune new nor thought of old can win. To dispossess me of such dear delight. What other object, then, could fill my sight, Enough of pleasance e'er. To kindle in my breast a new desire? (Boccaccio, 1886, p. 47).

The poetic text is a reprocessing of the twelfth book - The Metaphysics - by Aristotle ${ }^{11}$ with comments made by Averroes. ${ }^{12}$ "The obvious dualism among themselves and others is due to

\footnotetext{
${ }^{8}$ The tale of Frate Cipolla, one of Dioneo's contributions, finds themselves distinctive among the ten stories by virtue of their position (the last in each formal segment, with one exception) and freedom of argument (chosen by Dioneo himself, independent of the group's wishes).

9 Substance (ousia, "essence" or "substance"). Substance is defined as that which can neither be predicated of anything nor be said to be in anything. Hence, this man or that particular tree are substances. Later in the text, Aristotle calls these particulars "primary substances", to distinguish them from secondary substances, which are universals and can be predicated. Hence, Socrates is a primary substance, while man is a secondary substance. Man is predicated of Socrates, and therefore all that is predicated of man is predicated of Socrates.

${ }^{10}$ Some think that nothing besides perceptible things are substances, but others, like Plato, think that other things exist and that eternal things are more real. Thus Plato lists the Forms and mathematical objects as two substances, and the substance of perceptible things as a third (1028 i6-21). After mentioning modifications of Plato's view by his successors, Aristotle concludes that the project is to determine which of the foregoing statements are correct and which are not, which things are substances, whether there are substances besides perceptible things or not, in what sense these perceptible substances exist, whether there is some substance that exists apart from material things, and if so why and how, or whether there is no such substance in addition to perceptible things.

${ }^{11}$ What is known to us as metaphysics is what Aristotle called "first philosophy". Metaphysics involves a study of the universal principles of being, the abstract qualities of existence itself.

${ }^{12}$ Averroes, medieval Latin Averroes, also called Ibn Rushd, Arabic in full Abū al-Walīd Muhammad ibn Aḥmad ibn Muhammad ibn Rushd, (born 1126, Córdoba [Spain]_died 1198, Marrakech, Almohad empire [now in
} 
the plurality of God's names and the way God reports itself. God is the beauty and desire (fascination) after God there is only a desire for himself, after his own glory. God knows only himself. In God, the entity meets with an object in love and knowledge" (Gagliardi, 1999, p. 207). Under these conditions, God becomes the goal of human knowledge as knowledge of himself. It is in Him where intellectual fortune is satisfied according to Averroism. ${ }^{13}$ If in a state of happiness, where we find ourselves now, God is also constantly present, it is amazing. If $\mathrm{He}$ is in a state of even greater happiness than us, it is even more amazing. And $\mathrm{He}$ is in that state. $\mathrm{He}$ is also the life too, because the activity of intelligence is life, and he is the activity. His activity, which exists in itself, is the culminal and eternal life. In fact, we say that God is living, eternal and great, and so God belongs to eternal and infinite life, and thus this is God. "The substance loves primarily itself and thinks of itself. The beauty in this philosophical circle brings together all connotations. Beauty and good are the basic concepts that characterize God and with this duality the mind is split, mind that thinks of itself, and the beauty as a desire for itself" (Gagliardi, 1999, p. 207).

I burn for mine own charms with such a fire,

Methinketh that I ne'er

Of other love shall reck or have desire

(Boccaccio, 1886, p. 45).

The good that makes the mind (man) happy is God. The rational knowledge of God can be summarized in this synthesis. This is Averroistic concept of rational happiness. A sense of enjoyment for oneself has a common origin in God and is not preceded by anything. God is the subject of the pleasure of himself, because he is also the object at the same time. Therefore, there is no other desire. Desire and the object of desire have been mirrored one into another from the very beginning.
What other object, then, could fill my sight,
Enough of pleasance e'er
To kindle in my breast a new desire?
(Boccaccio, 1886, p. 45).

"The Answer is: none. It is worth noting that the concept of the object became part of the intellectual language, as seen in the work of Aristotle, in terms of aim and end, to which the peace of desire and knowledge of someone, or something is leading. There can be nothing new in God because the relationship with himself is closed and formed only by himself' (Gagliardi, 1999, p. 208).

2) Pampinea: Quantitas, Quantity ${ }^{14}$

The main theme of the second song is also love. The original text, which speaks about the Categories, is scattered in the episode and can only be collected in its complexity. All the characters of the quantity are present without reciprocal alignment and only function as a new

\footnotetext{
Morocco]), an influential Islamic religious philosopher who integrated Islamic traditions into ancient Greek thought.

13 The doctrines of Averroes, whose teachings were mainly written in the form of Neoplatonically influenced commentaries on Aristotle differed from Avicennism in affirming that the whole world is created all at once by God directly, eternally, and continuously and that individual souls are not immortal except insofar as they participate in a universal intellect.

${ }^{14}$ Quantity (poson, "how much"). This is the extension of an object and may be either discrete or continuous. Furthermore, its parts may or may not have relative positions to each other. All medieval discussions about the nature of the continuum, of the infinite and the infinitely divisible, are a long footnote to this text. It is of great importance in the development of mathematical ideas in the medieval and late Scholastic period.
} 
warp. Concepts like "Each", "Little", "More", "Larger", "The same", "How many" form part of the language of this category and determine its logical function. The relationship between sizes and the size itself is displayed through the superior, which defines the correlation between different parts. We can go through the whole song and watch a tangle of quantitative relationships that make up the real link between the person singing and the subject of their love.

Thou settest, Love, before these eyes of mine

Whenas thy fire I entered the first day,

A youngling so beseen

With valour, worth and loveliness divine,

That never might one find a goodlier, nay,

Nor yet his match, I ween.

So sore I burnt for him I still must e'en

Sing, blithe, of him with thee, my lord most high

(Boccaccio, 1886, p. 126).

"In these verses, quantity is clearly expressed. It is also supported by negation in the lyrics. The opposite of the same is uneven. Both expressions correspond to Aristotle's concept of quantity" (Gagliardi, 1999, p. 209). Boethius ${ }^{15}$ explains the fact that, just after the essence, the author deals with quantity, even before quality. The reason for this is that the first, unlike the second, covers everything. Each thing is one or more, it is still the same mass, which itself does not form or poses qualitative definition.

3) Lauretta: Qualitas, Quality ${ }^{16}$

All species come from God and connect with matter to create individual living creatures. The type or universal form becomes a basic form of beings, while the connection with the material condemns them to death. He who reigns over the sky and the stars, created me graceful and beautiful for his enjoyment, and gave the creatures down there a sign of beauty too, the beauty that marks his face. "God created a universal form to give every sensible creature a sign of beauty that is around him. But the beauty that is around God is God himself. God is the beauty that knows itself and loves itself. This can be understood as the most complex part of Averroism. The theory on intelligent species, science, and the way to get from the species that originated from the matter to the vision of God" (Gagliardi, 1999, p. 216).

Inside the beauty that a person can experience and which can bring him to the knowledge of the beauty of God, hides the indirect expression of the definite. The struggle between the spiritual nature of the species and their matter, the weakness that brings death, represents the critical moment of individuality. Species remain versatile, but the creature is identified by gaining a tangible body. The final comment of the author gives this contrast a realistic understanding of the song with the way he interprets it. The divine, the best and most real reason. This difference appears in all the songs. From sensory perception, through the intellect (high because it was cultivated by knowledge and virtues by the model of Dante Alighieri). ${ }^{17}$ There is an obvious reference to the first song and to God, which is mirrored (eternally, indefinitely) in its own glory. From the beauty of woman to the beauty of God, notice here the path of intellectual knowledge, which assumes previous sensory knowledge of the form. "We

\footnotetext{
${ }^{15}$ Boethius (c. 480-524/525) was one of the most influential early medieval philosophers. His most famous work, The Consolation of Philosophy, was the most widely translated and reproduced secular work from the 8th century until the end of the Middle Ages.

${ }^{16}$ Quality (poion, "of what kind or quality"). This is a determination which characterizes the nature of an object.

${ }^{17}$ Regarded as one of the finest poets that Italy has ever produced, Dante Alighieri is also celebrated as a major influence on Western culture. His masterpiece, the epic poem Commedia (The Divine Comedy), is universally known as one of the great poems of world literature.
} 
are totally in the Aristotelian physics (in texts such as De generatione et corruptione ${ }^{18}$ and all those Aristotle's [sic] works where principles such as form, matter, lack of the form are mentioned). There is a complete discrepancy, the contrast that finally leads to death. Lack does not know the form just because of the ontological relationship contradicts the form. On the other hand, the contrast with deficiency, which is expressed here in human form (low appreciation, despising me) is part of the quality" (Gagliardi, 1999, p. 216).

4) Filostrato: Ubi, Position ${ }^{19}$

Position is the settlement of personality in a certain state of skill, quality and passion. Filostrato's "Abito" represents an internal condition that becomes permanent over time. These are character definitions that are gradually acquired and difficult to remove. Filostrato's habitus (his state) is the fruit of unreturned love that brings hopelessness and death. It was a woman who left him for another man. "The time logic should give an answer to the question of the importance of the persistence of the individual's internal status. The link between the past, presence and the future shows the continuity of anxiety: this is the habitus" (Gagliardi, 1999, p. 224). "However, Fortune, the enemy of the happy, denied him this solace, for that, whatever might have been the cause, the lady, after complying awhile with Tedaldo's wishes, suddenly altogether withdrew her good graces from him and not only refused to hearken to any message of his, but would on no wise see him; wherefore he fell into a dire and cruel melancholy; but his love for her had been so hidden that none guessed it to be the cause of his chagrin. After he had in divers [sic] ways studied a man to recover the love he seemed he had lost without his fault and finding all his labour vain, he resolved to withdraw from the world" (Boccaccio, 1886, p. 158).

"This is an 'amore heroes', a deadly disease that has already evolved in [the] poetic development of Guido Cavalcanti. ${ }^{20}$ Maybe it's him, who is hiding in a persona that speaks the poetic language of Cavalcanti. In the second story of that day, the young man finds himself in the same situation" (Gagliardi, 1999, p. 224). Obviously, habits are statuses that last long and are hard to change. Habit is different from skill because it persists longer and resists change, while skill can be changed more easily. Filostrato himself points out that his state of being submissive to love and grief has already become a habit, and that it has not changed since his beloved has left him and remains the same until his death.

The habit Filostrato is singing about is the fruit of missing love. The loss of a loved one is the cause of enormous pain in his soul, which resulted in the loss of love for life and desire to die. To be able to define the habitus, it is necessary to meet the condition of persistence over time. In this case it is time inside the story. The past and probable future show that the state of anxiety is already rooted, and it is impossible to eliminate its consequences. The reason that caused the grief has already become a part of nature and transformed its existence into fate.

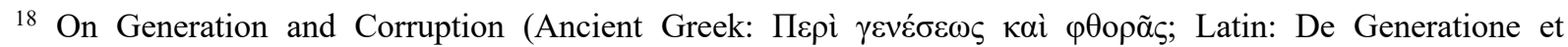
Corruptione), also known as On Coming to Be and Passing Away) is a treatise by Aristotle. Like many of his texts, it is both scientific, part of Aristotle's biology, and philosophical. The philosophy is essentially empirical; as in all of Aristotle's works, the deductions made about the unexperienced and unobservable are based on observations and real experiences.

${ }^{19}$ Position (keisthai, "to lie"). The examples Aristotle gives indicate that he meant a condition of rest resulting from an action: 'lying', 'sitting'. Thus, position may be taken as the end point for the corresponding action. The term is, however, frequently taken to mean the relative position of the parts of an object (usually a living object), given that the position of the parts is inseparable from the state of rest implied.

${ }^{20}$ Guido Cavalcanti (c. 1255 - 1300) was an Italian poet who was one of the founding members of one of the most important movements in all of medieval poetry, the Dolce Stil Novo (The Sweet New Style) which in the eyes of many scholars would mark the transition from classical poetry of the medieval world to the new emerging styles of what would become the Renaissance.
} 
Love, with clasped hands I cry thee mercy, so

Thou mayst betake thee where my lord doth dwell.

Say that I love and long for him, for lo,

My heart he hath inflamed so sadly well;

Yea, for the fire wherewith I'm all aglow,

I fear to die nor yet the hour can tell

When I shall part from pain so fierce and fell

As that which, longing, for his sake I dree

In shame and fear; ah me,

For God's sake, cause him know my torment dire

(Boccaccio, 1886, p. 488).

"Pain and crying, which were born in the abandoned heart, still persist. This is the habitus. The state of pain turns to the state of hope. Filostrato speaks of the presence from which the unchanged future can be estimated. His knowledge was rooted into the constancy and became a fate that can no longer be decommitted" (Gagliardi, 1999, p. 224). It confirms the mortality of the soul of an individual but remains an unspoken finding of the immortality of the sense of human beings as one of the species. This is a key point of the whole Averroism of the soul, which does not allow for ambiguity. Filostrato believes in the mortality of the personal soul. At the same time, religious virtues can also be found in the text: faith, hope, mercy. All these virtues associate man with God. The soul, which, at the moment of death curses faith, hope and mercy, indirectly curses God himself. This soul is foreign to the Christian vision. The death of the soul is suddenly confirmed in a single idea, the absence, or rejection of the Christian God, and the Christian vision of man. Here is a deeper, hidden meaning in the text that opens not only the following text, but where the sense snaps into the next.

5) Dioneo: Quando, Time ${ }^{21}$

"Since every motion is in time and a motion may occupy any time, and the motion of everything that is in motion may be either quicker or slower, both quicker motion and slower motion may occupy any time: and this being so, it necessarily follows that time also is continuous. By continuous I mean that which is divisible into divisibles that are infinitely divisible: and if we take this as the definition of continuous, it follows necessarily that time is continuous" (Aristotle, 2019, p. 747). "The presence as a moment in which there may be memory along with expectations, is located at this border, where memories of the past are suspended and smoothly pass to expectations of the future, which once occurs" (Gagliardi, 1999, p. 227). Dioneo is singing about this mental state, the moment of suspension between memories of love and the expectation of a happy future.

O Love, the amorous light

That beameth from yon fair one's lovely eyes

Hath made me thine and hers in servant-guise.

The splendour of her lovely eyes, it wrought

That first thy flames were kindled in my breast,

Passing thereto through mine;

Yea, and thy virtue first unto my thought

Her visage fair it was made manifest,

Which picturing, I twine

And lay before her shrine

All virtues, that to her I sacrifice,

${ }^{21}$ (pote, "when"). Position in relation to the course of events. 
Become the new occasion of my sighs

(Boccaccio, 1886, p. 294).

This confirms that love, as for Aristotelean knowledge, comes through vision. The imagination of the face of a beloved woman thus emphasizes the difference between a real person and a sighting. The power of imagination thus can tame the overwhelming tension of desires and in the absence of a beloved woman will not allow the predominant tendency to selfdestruction. The sighting of a beloved woman thus creates an independent inner life. "We should not doubt that Boccaccio himself is identified by the picture of Dioneo. Not just because he re-used a name that had previously belonged to him. But there is an autobiographical followup in the intellectual style of fantasy love, apparently referring to the "Amorosa visione"" (Gagliardi, 1999, p. 227).

6) Elissa: Habitus, Have ${ }^{22}$

The category shall indicate ownership where one thing is the property of the other. Similar to how a woman is owned by a man. This is the case with this love song where the woman sings about how she feels caught by the man who refuses her. "Possession is denominated in many ways. In one way as the action of a thing according to the nature of that thing, or according to the impulse of it. Wherefore, both a fever is said to possess a man and tyrants are said to possess states and those that are clothed a garment. And in another way we term possession as that in whatever anything is inherent, as being receptive; as, for instance, the brass possesses the form of a statue, and the body possesses disease" (Aristotle, 2007, p. 118, 119). "The song of Elizina presents the picture of a bird, a big vulture that plunging on his prey, flies over her and keeps her clutched in her claws. On the background the story flows. She, a young girl who found herself in the struggles of love and gave up any defense because he thought she would find peace this way. When she was spotted defenseless by the cruel tyrant Cupid, he immediately plunged and rushed her claws to her to imprison her" (Gagliardi, 1999, p. 231).

Then, wound about and fettered with thy chains,

To him, who for my death in evil hour

Was born, thou gav'st me, bounden, full of pains

And bitter tears; and syne within his power

He hath me and his rule's so harsh and dour

No sighs can move the swain

Nor all my wasting plaints to set me free

(Boccaccio, 1886, p. 321).

7) Filomena: Actio, Action ${ }^{23}$

Action and passion are in mutual relationship. It can be defined as an act of modifying something. The woman sings about the love connection, as she first experienced it and perceived it with all her senses.

If once again I chance to hold thee aye,

I will not be so fond

As erst I was to suffer thee to fly;

Nay, fast I'll hold thee, hap of it what may,

\footnotetext{
${ }^{22}$ State or habitus (echein, "to have"). The examples Aristotle gives indicate that he meant a condition of rest resulting from an affection (i.e. being acted on): 'shod', 'armed'. The term is, however, frequently taken to mean the determination arising from the physical accoutrements of an object: one's shoes, one's arms, etc. Traditionally, this category is also called a habitus (from Latin habere, "to have").

${ }^{23}$ Action (poiein, "to make" or "to do"). The production of change in some other object.
} 
And having thee in bond,

Of thy sweet mouth my lust I'll satisfy.

Now of nought else will I

Discourse. Quick, to thy bosom come me strain;

The sheer thought bids me sing like lark at morn

(Boccaccio, 1886, p. 364).

The correlation between activity and passivity in Aristotle's categories refers to a verbal form, while these two concepts of Aristotle's are discussed in his other works. In general, activity means an act that changes something that can be changed. "There are three things in the soul that are authoritative over action and truth: sense perception, intellect, and longing. But of these, sense perception is not the origin of any action, and this is clear from the fact that beasts have sense perception but do not share in action" (Aristotle, 2011, p. 116). "Goodwill seems, therefore, to be the beginning of friendship, just the pleasure stemming from sight is the beginning of erotic love. For no one falls in love who is not first pleased by someone's appearance- though a person who delights in another's looks does not for all that fall in love, except whenever he also yearns for the person who is absent and desires his presence. In this way, therefore, it is not without goodwill to become friends, but those who have goodwill do not for all that feel friendly affection" (Aristotle, 2011, p. 196).

8) Panfilo: Situs, Place ${ }^{24}$

The place itself is known and evident for Aristotle. There is something mysterious in this song, and it appears in the final verse. Where did Panfilo actually live? And where is that place which made him so happy? It is Dante's language that accompanies us to a place normally inaccessible, where full happiness can be achieved - bliss.

Who might conceive it that these arms of mine

Should anywise attain

Whereas I've held them aye,

Or that my face should reach so fair a shrine

As that, of favour fain

And grace, I've won to? Nay,

Such fortune ne'er a day

Believed me were; whence all afire am I,

Hiding the source of my liesse thereby

(Boccaccio, 1886, p. 427).

"This place, which cannot be described and approached, is supernatural. It's the way we approach God in Dante's Divine comedy and the storyteller is Dante himself who has visited this mysterious place personally. Boccaccio along with Guido Cavalcanti (Filostrato) and Dante becomes the secret hero of his work" (Gagliardi, 1999, p. 235). In order to fully understand the meaning of what Panfilo has experienced and what brings him this sense of happiness, it is important to guess where the places were. The final comments show that the experience of Panfilo compared to the other young people was exceptional. None of them can grasp the words of the song, and whatever they try, no one has captured its true meaning. When Panfilo's song ended, everything in it was explained for the present people. All of them focused on the lyrics with more intensity than appropriate, and they tried to guess why he wanted to keep secret what he sang about. They assumed different explanations, but no one was near the truth. "Despite diversity of the places that are mentioned in the song, it creates a significant space in which the identity of the character is located. Panfilo talks about places that are not tangible and belonging

\footnotetext{
${ }^{24}$ Place (pou, "where"). Position in relation to the surrounding environment.
} 
to his inner world, or to the metaphysical order" (Gagliardi, 1999, p. 235). The theme of intellectual happiness has already been discussed in the first and third poem and has now returned in full significance. The song expresses intellectual happiness, which the figure tells from his own experience. Dante sees Boccaccio as the one who has experienced intellectual happiness through sensory experience of transcendence ${ }^{25}$ and gained the knowledge of the highest goodness on his way to God, as he says in the Divine Comedy.
A flame of love that rest nor day nor night
I find; for, by some strong unwonted spell,
Hearing and touch
And seeing each new fires in me did light,
Wherein I burn outright
(Boccaccio, 1886, p. 364).

"As it seems Panfilo is in a state (synonym of the word habitus) of lasting happiness. His State of happiness surpasses it, which can be a scare of senses, because it is greater and more valuable than the happiness they offer to the senses. This is a key point where intellectual happiness replaces all biological activity and its objectives" (Gagliardi, 1999, p. 237).

9) Neifile: Relatio, Relationship ${ }^{26}$

A relationship combines two things. Through a logical link, things can have a relationship with each other. The most common method of relationship is comparison. The similarity of things that can be in a reciprocal relationship is based on logical roots.

I go about the meads, considering

The vermeil flowers and golden and the white,

Roses thorn-set and lilies snowy-bright,

And one and all I fare a-likening

Unto his face who hath with love-liking

Ta'en and will hold me ever, having aye

None other wish than as his pleasures be

(Boccaccio, 1886, p. 461).

Similarity is based on the principle of substitution: the flower takes over the place of a beloved man: the pleasure of seeing flowers is like seeing his face. "Neifile is like the characters in Botticelli ${ }^{27}$ paintings, she collects spring flowers on the meadow. When comparing the beauty and colors of flowers to the beauty of the face of her beloved, in her gestures there is an incarnated relationship" (Gagliardi, 1999, p. 239). "Things are relative as double to half, and treble to a third, and in general that which contains something else many times to that which is contained many times in something else, and that which exceeds to that which is exceeded. As that which can heat to that which can be heated, and that which can cut to that which can be cut, and in general as the measurable to the measure, and the active to the passive. Knowable to knowledge, and the perceptible to perception" (Aristotle, 2019, p. 2392). Properties of objects are compared through their mutual relationship. The beauty and colour of flowers is compared to the beauty of a beloved man's face. Neifile loves and is loved, she feels the certainty of

\footnotetext{
${ }^{25}$ Existence or experience beyond the normal or physical level.

${ }^{26}$ Relation (pros ti, "toward something"). This is the way in which one object may be related to another.

${ }^{27}$ Sandro Botticelli, original name Alessandro di Mariano Filipepi, (born 1445, Florence [Italy] — died May 17, 1510, Florence), one of the greatest painters of the Florentine Renaissance. The Birth of Venus and Primavera are often said to epitomize, for modern viewers, the spirit of the Renaissance.
} 
eternal love. Her only desire is to satisfy the men's wishes. The relationship of substitution can become apparent: the flower takes the place of the person through smell and sight.

Ay, and that pleasure which the eye doth prove,

By nature, of the flower's view, like delight

Doth give me as I saw the very wight

Who hath inflamed me of his dulcet love,

And what its scent thereover and above

Worketh in me, no words indeed can say;

But sighs thereof bear witness true for me.

(Boccaccio, 1886, p. 461).

"Words are not enough to express the pleasure that comes from the flowers, the physical enjoyment that crosses the senses, just as we perceive the delight of the beloved man. The relationship thus passes through the text and connects people and things in one symbolic unity to flow without obstacles" (Gagliardi, 1999, p. 241).

\section{0) Fiammetta: Passio, Passion/Affection ${ }^{28}$}

Passion is the opposite of activity, but in this song, it is about singing through jealousy of passionate love. "But to these jealous men will on no wise consent; nay, those days which are gladsome for all other women they make wretcheder and more doleful than the others to their wives, keeping them yet closelier straitened and confined; and what a misery and a languishment this is for the poor creatures those only know who have proved it. Wherefore, to conclude, I say that what a woman doth to a husband who is jealous without cause should certes not be condemned, but rather commended" (Boccaccio, 1886, p. 336). The list of Aristotelian categories concludes with Fiammetta and her jealousy. The summary of all categories thus forms nature. In the Women's Valley, the bathing of young people became a depiction of the intellectual act, knowing the whole meaning, which predetermines the happiness of the knowledge of God by Averroes. The integrity and the plasticity of symbols allows Boccaccio to introduce the most complex philosophical topics. The category of passion refers to the whole nature and indicates the ability to endure something or to be transformed by an active principle. "Passion also is sometimes reckoned as courage; those who act from passion, like wild beasts rushing at those who have wounded them, thought to be brave, because brave men also are passionate; for are passion above all things is eager to rush on danger, and hence Homer's put strength into his passion' and 'aroused their spirit and passion and hard he breathed panting' and his blood boiled'. For all such expressions seem to indicate the stirring and onset of passion" (Aristotle, 2019, p. 2689). Jealousy accompanies the fierce passion and becomes the true object of the song. Love (desire) and jealousy (envy and hatred towards another woman) have one origin and affect each other. It seems that anger (desire for revenge) is a typical form of emotional jealousy.

If love came but withouten jealousy,

I know no lady born

So blithe as I were, whosoe'er she be.

If gladsome youthfulness

In a fair lover might content a maid,

\footnotetext{
${ }^{28}$ Affection (paschein, "to suffer" or "to undergo"). The reception of change from some other object. It is also known as passivity. It is clear from the examples Aristotle gave for action and for affection that action is to affection as the active voice is to the passive. Thus, for action he gave the example, 'to lance', 'to cauterize'; for affection, 'to be lanced', 'to be cauterized.' The term is frequently misinterpreted to mean a kind of emotion or passion.
} 


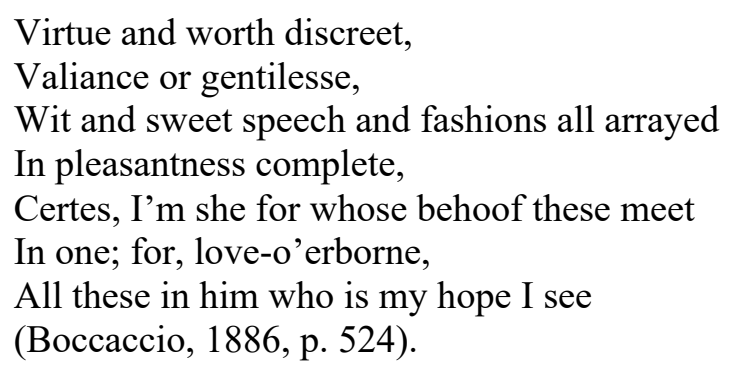

\section{Conclusion}

"When this journey of knowledge ends, they will be able to return to the city. They will know how to renew social order and laws. When young people return to Florence, their initial negative experience is linked to the knowledge of natural wisdom and life, just like in the church, at the place they first saw death and destruction throughout their devastating power, the utopian moment of their journey for exploring ends there, at the place of reconciliation with death, accentuating it by the contradiction with their intellectual experience. The initial utopia thus becomes the intention, because now they know what death and destruction have brought to them" (Gagliardi, 1999, p. 181). "Protecting life is the main goal of every human and natural activity. Life is the existence of living beings" (Aristotle, 2018, p. 83), says Aristoteles in his work On the soul. "Life is a natural activity that refreshes itself according to the universal order until it achieves the primary goal, to the birth of a human being. Words that Pampinea said in the church become the main idea, the general law and the code to interpret the work, because it is Logos the principle of the sensible being.

From the metaphysical to physics, from ethics to rhetoric and politics, life is a project that expands to become the foundation of being and thinking. The goal of all goals, the greatest good that makes the next good" (Gagliardi, 1999, p. 181). When the two texts are combined, the intellectual terminology is hidden into the interior of the lingual storyboard, which repeals the specificity of the philosophical significance. This creates the text which is dissolved in another text and contains itself, veiled, and practically unidentifiable as a separate text. This is a text that no longer exists and has become a watermark of another storyboard. Once identified, dogmatic terminology must be converted into the original philosophical text and only then proves its own syntax and meaning. The final canzones of Decameron have such a structure; a weak storyline with intellectual terminology, renovated in the obvious text of love poetry.

\section{References}

ARISTOTLE (1961): Physics. Lincoln: University of Nebraska press.

ARISTOTLE (2007): The Metaphysics. Mineola, NY: Dover publications.

ARISTOTLE (2011): Nicomachean ethics. Chicago: The University of Chicago Press.

ARISTOTLE (2018): On the soul and other psychological works. Oxford: Oxford University Press.

ARISTOTLE (2019): Complete works. eBook: MVP.

BOCCACCIO, G. (1886): Decameron. London: The Villon Society.

BRADSHAW, D. (1998): Lecture notes: Aristotle. Patterson: University of Kentucky. [online] [Retrieved May 4, 2019] Available at: http://www.uky.edu/ jjord0/Aris.htm

GAGLIARDI, A. (1999): Giovanni Boccaccio Poeta Filosofo Averroista [Giovanni Boccaccio: Poet, philosopher and Averroist]. Catanzaro: Rubbettino

GAGLIARDI, A. \& KOPRDA, P. (2016): Podklady $k$ hermeneutike stredovekej talianskej literatúry [Handouts to the hermeneutic of the medieval Italian literature]. Nitra: UKF Nitra. OKÁL, M. (1953): Grécki atomisti a Epikúros [Greek atomists and Epicuros]. Bratislava: SAV. 